\title{
Narratives of difference and sameness
}

\author{
Author: \\ Jacobus J. (Jakkie) Strachan ${ }^{1}$ \\ Affiliation: \\ ${ }^{1}$ Department of Practical \\ Theology, University of \\ Pretoria, South Africa \\ Correspondence to: \\ Jakkie Strachan \\ Email: \\ jakkiestrachan@gmail.com \\ Postal address: \\ PO Box 161, Harrismith 9880, \\ South Africa \\ Dates: \\ Received: 02 Mar. 2015 \\ Accepted: 04 May 2015 \\ Published: 03 July 2015 \\ How to cite this article: \\ Strachan, J.J., 2015, \\ 'Narratives of difference \\ and sameness', Verbum et \\ Ecclesia 36(2), Art. \#1445, \\ 8 pages. http://dx.doi. \\ org/10.4102/ve.v36i2.1445 \\ Note: \\ Jakkie Strachan is a youth \\ worker at DRC Lynnwood in \\ Pretoria.
}

This article was written as part of the research for a MTh degree that was done under supervision of Prof Julian C. Müller, Department of Practical Theology, University of Pretoria, South Africa.

Research Participant in the Ubuntu-Research project of the University of Pretoria. Professor Julian Müller and Doctor Wilhelm van Deventer are the project leaders of Cluster 2 of the Ubuntu Research Project of the Centre of the Advancement of Scholarship (CAS), University of Pretoria. Cluster 2 focusses on the theological aspects of the research project titled: 'The meaning and value of Ubuntu in human and social development in Africa'.

\section{Read online:}

Scan this QR code with your smart phone or mobile device to read online.
As an Afrikaner man doing research on $u b u n t u$, what are the possibilities for meaningful research? In this article, some aspects of the difficulties and possibilities that may be encountered in such a research programme will be explored. Within a postmodern worldview, and framed within postfoundational practical theology, social-constructionism, a narrative hermeneutic metaphor and autoethnography will be used as tools to explore some difficulties and possibilities of such a research undertaking.

\section{Introduction}

I am a white Afrikaans-speaking man and I am 28 years old. I am currently employed by one of the bastions of apartheid society, the Dutch Reformed Church. I also grew up on a farm in Harrismith in the Free State. In a sense, on the surface at least, I could have been a poster child for the apartheid system. A system of which the consequences are still felt every day, some of which are that as an Afrikaner I am still privileged, even after 21 years of a democratic South Africa. Although I have lived most of my life within this new political system, the opportunities that were afforded the generations of which my parents and grandparents were part still ensure more opportunities for me and other white people than are available to most black people of our generation.

Yet, I am involved in the Ubuntu Research Project of the Centre for the Advancement of Scholarship (CAS), University of Pretoria, a project wherein practical theological research will be carried out on certain aspects of $u b u n t u$ and the complexities of this term.

Ubuntu can be described as a way of being that is indigenous and unique to Africa. A way of experiencing life and the lives of others with very specific characteristics and focusses which formed and form part of different African cultures. Relatedness, in some form or another, is inherent in descriptions of ubuntu: human relatedness to nature (ed. Murove 2009a:29; Shutte 2009:87); living humans' relatedness to the dead (Mbiti 1969:141; Shutte 2009:96); or 'living dead' (Hallen 2009:138; Mbiti 1969:141); and relatedness between humans (Munyaka \& Motlhabi 2009:66). It is an awareness of this connectedness of humanity (Nussbaum 2009:101), an awareness that 'I am, because we are; and since we are, therefore I am' (Mbiti 1969:108); and 'I feel the other, I dance the other, and therefore I am' (Senghor in Nussbaum 2009:101). Humanity is connected in the deepest, most profound sense of being; a worldview wherein being is always shared, wherein it flows out of the existence of humans in relationships.

Therefore the primary question is not whether a person can do meaningful research on a topic, which forms part of a culture, or worldview of which the researcher is not part of, or foreign to, the validity of this has been shown (Ember, Ember \& Peregrine 1998:592; Van Huyssteen 2006:13). The question is can I, as an Afrikaner man, a symbolic pillar of the past in a post-apartheid society, do research with integrity on $u b u n t u$, an aspect of African culture and society which was, and still is, the victim of that very apartheid society, in the contemporary South African political milieu. Further, can I as an emblem of the political system that caused indescribable destruction to those cultures sharing a worldview shaped by ubuntu values, deliver research findings that may be valid.

Integral to this research will be the acknowledgement of the relationships between the political milieu and the specific research problems. In the positioning sections of this article that will follow, I will try to show that interrogating certain worldviews, philosophical and theological insights and research methods it may be able to construct a position from which valid scientific research can be carried out. Understanding the role of the contemporary political milieu is integral to the research and ensuring the integrity thereof. Van Huyssteen (2006:50ff.) has shown what influence 
'extra scientific' political or moral values can have on a research field such as palaeoanthropology. How the political and moral climate of the post-Holocaust period shaped the interpretation of 'scientific facts' in palaeoanthropology.

In a postconflict society such as South Africa, where humanity was defined by political ideologies, and where these same definitions of humanity are still used to redress the injustices of that past, it will be irresponsible not to acknowledge these factors.

This is also important for any research done on $u b u n t u$. Praeg (2014:x) argues that it is the political usage of the term that warrants critical reflection on its possibilities of meaning in a South African context. Furthermore, he argues that:

There is no such thing as apolitical knowledge and every claim to be pursuing knowledge as 'and end in itself' is first and foremost a political statement or claim that seeks to conceal from itself and everyone else the simple fact that all forms of knowledge work to sustain what one could call their implicit socio-epistemic communities and the institutions that such communities have created to perpetuate and sustain their interests. (p. 4)

How will my complicity in past injustices, based on demographic markers (Afrikaner, white male, 28 years of age, middleclass) influence research I may do on $u b u n t u$, a very complicated concept that forms part of, even the basis of, the very cultures that were subjugated to the injustices of apartheid.

By using a postfoundationalist, social-constructionist and narrative lens, I will try to position myself through some of the narratives that I myself have lived and experienced, as well as narratives that I have been witness to. By using autoethnography I will try to position myself in certain narratives and meanings. The narratives in my life are South African narratives.

After setting out my interpretation of the narratives I have been a part of, I will try to explore some of the questions of this research project. As part of exploring the problematic issue of my participation and my manner of participation in such a project, I will share my own lived experiences in order to set the scene, lay bare privileges, prejudices (that I am aware of), and adopt and promote a metaphor for research.

It is not only about research - it is also personal. As a citizen of this country life and life in South Africa after apartheid is a personal matter. Where do I fit in? What does my history make of me - an Afrikaner, a South African, or both?

\section{Theological and philosophical positioning}

This research project will be conducting practical theological research from a certain paradigm with the help of specific ontological and epistemological tools. A postmodern worldview (Burr 1995:13; Routledge 2000:700) will form the ontological background, and will be explored further by using concepts such as socialconstructionism, the narrative metaphor, autoethnography and a postfoundational approach to research.

Freedman and Combs (1996:22) describe postmodernism as a worldview wherein knowledge is not seen as an entity existing in and of it, but is rather something created or compiled in communities, by people who have access to specific kinds of knowledge. All knowledge, even scientific is socially constructed (Gergen 1999:50ff.; cf. Sarup 1988:121). The reality, which we experience, is thus not something outside of ourselves, which we receive as an existing entity, but is actually created and constituted by us. A researcher using this research paradigm understands that the knowledge and reality that he or she uses is also created in the interaction between people and their realities with one another. Her or his reality is not normative, is not prescriptive determined by the realities that they try to research; there is thus a focus on the complexities of this new reality with which they are confronted, and not on making these realities conform to their own understanding of reality.

The hermeneutic metaphor developed from the work of Ricoeur on interpretation and meaning (Demasure \& Müller 2006:410), where interpretation is not seen as only the interpretation or understanding of written texts, but as an integral part of the everyday life of every human being (Ricoeur 1981:53; cf. Sarup 1988:120). Foucault and Derrida developed an understanding of knowledge that is socially constructed in specific contexts (Burr 1995:2).

Social-constructionism and the narrative metaphor are complementary ways of understanding the ways, in which people create, maintain, destroy and recreate meaning from their lives. It is also a way of unpacking the cultural contexts, in which all knowledge is created, especially knowledge that is seen as authoritative truth: 'Social constructionism prefers storytelling to an argumentative discourse' (Demasure \& Müller 2006:415).

Within a social-constructionist approach language is viewed as both that which gives humans the structure with which to express meaning (Demasure \& Müller 2006:141), as well as that which creates action. When people speak, meaning happens (Ricoeur 1981:133). Language is the building block of meaning, giving meaning, and creating meaning. The researcher is thus aware of the importance of the role of language, the power inherent in spoken words. As language grows with meaning, meaning cannot be imposed on others. The same experiences and objects will be described with different words, not only in the sense that an Afrikaans and a Zulu word for the same object does not sound the same, but that the words that are used for the same object will have different connotations and reservoirs of meanings. When research is done, any cultural translation must accept a loss of meaning. The researcher will be reminded that the culture that research is carried out in will never be quantifiable, even if some experiences and meanings can be measured. 
Life and the experiences constituted are arranged in narratives, these narratives form the 'texts' of our lives, and can be studied through the insights of hermeneutics. All of these narratives, or 'texts', are lived in specific contexts with specific information, some of which is local, and some of which is part of a global context:

A narrative perspective helps to 'unpack' some narratives that are informed by cultural power (White 2011:5). It involves conversations with other people and induces interactions in communal spaces. There is no hierarchy between subject and object. (Freedman \& Combs 1996:172)

By listening to narratives then, the reservoirs of meaning behind one word or one phrase may become clearer. By understanding meaning with the narrative metaphor the researcher will listen differently, not for objects, but for stories.

The validity of narrative research hinges on the acceptance of the gathered evidence and the validity of the offered interpretation (Polkinghorne 2007:478). The evidence may be viewed as invalid from a positivistic point of view as feelings are thought to be disavowed in scientific research. However, these feelings, or 'internal dialogues' are very important when dealing with issues of meaning, as sadness, discomfort or any other feelings may be the exact experience which opens up the researcher to new meaning (Leavy 2009:41). Including these emotions into the research provides the researcher and coresearchers with a better understanding of the meanings of the other they are trying to understand. Using the narrative metaphor helps us to understand our own implicit and subconscious ways of interpreting these experiences, as we can retrace and retell our own narratives to discover the experiences and stories that shape our understanding of reality. There is thus no 'expert' conducting research on 'subjects' - but only coworkers or coresearchers conducting research through their respective narratives and worldviews. I will try to understand my own worldview and understanding of life by unpacking some narratives from my own life. Only then can I try to help others unpack their own narratives - and in that process, it is hoped that our different narratives and the different meanings we give them will bring a new understanding. This will be achieved autoethnographically. Autoethnography is a narrative form of enquiry that uses the narratives of all coresearchers as information and as lenses by which the other involved narratives are viewed and analysed (Butz \& Besio 2004; Ellis \& Bochner 2000:729; Schingaro 2014:706). Using 'analytical' rather than 'evocative' autoethnography will ensure that research is not done merely to evoke emotion, but to relfect critically on these narratives (Taber 2010:14). The emotions that are welcomed in research must be reflected upon critically.

Autoethnography will thus be done as practical theology, which will be framed within the postfoundationalist paradigm. The postfoundationalist research paradigm uses the embodied nature of all human understanding to bridge the gap between postmodern relativism and modernistic absolute truths. Research can be carried out in such a way that the knowledge gained from one context can be used in other contexts, without it being seen as the absolute, authoritative truth for all contexts (Van Huyssteen 2006:5, 10, 15). The focus on contextuality of the postmodern worldview and the importance of absolute truths of the modern worldview are reworked, thereby acknowledging the importance of context, but also acknowledging that some information can be shared through different contexts. Van Huyssteen does not use the same language as social-constructionism in his exposition of the grounds for share rationality, but Müller (2005:299) argues that the language and paradigms are compatible.

Postfoundationalism will provide the comprehensive language needed to do research in very different contexts, and to do interdisciplinary research (Müller 2011:1,3). This is especially relevant for the ubuntu research project where different disciplines will do research on the same broader subject matter, and where different traditions of thought will be in constant conversation.

\section{Positioning and an African way of life}

I have described certain lenses and paradigms developed within Western intellectual traditions which I aim to use in research on the topic of ubuntu. I will now try to illustrate why these paradigms may be suited for research on this topic.

Relatedness in general, but also specific instances is continually stressed as integral parts of the functioning of ubuntu; some examples are:

- human relatedness to nature (Murove 2009b:29; Shutte 2009:87)

- human relatedness to the dead (Shutte 2009:96), or 'living dead' (Hallen 2009:138)

- relatedness between humans, which forms the basis of an ethic whereby people are never a means to an end (Munyaka \& Motlhabi 2009:66).

Murove (2009a) cites Whitehead's radicalisation of the concept of relationality to explain something of the way in which relatedness is understood within African ethics:

Whitehead radicalises the concept of relationality so far as to suggest that those things we are accustomed to seeing as individuals are actually societies, a term he uses to imply the derivative nature of cosmological and social order. Thus he writes: The members of the society are alike because, by reason of their common character, they impose on other members of the society the conditions which lead to that likeness'. Whitehead would appear to be saying that a person's identity is derivative from the past as well as the present. This is only possible if the individual is relationally and interrelationally constituted. (p. 27)

Relationshipsand relatedness are central to any understanding of $u b u n t u$ and the ethical consequences thereof:

An ethic that arises from a civilization sensitized to relatedness among all that exists can only be an ethic about relatedness. Thus, in African ethics, relatedness is not restricted to human 
relations but extends to the natural environment, the past, the present and the future. (Murove 2009a:28)

An ethic based on ubuntu values includes all of creation, and is based on the relatedness of the individual to other individuals, the community and every part of the physical reality.

Relatedness is also essential to identity and personhood. Murove (2009a) writes:

What it means to be human is something that the individual derives from the community; there is simply no dichotomy between the individual and the community because the individual and the community exist in a symbiotic relationship. (p. 30)

However, a person can also be seen as 'the basis, centre and end of everything; izinto (all other things) only make sense in relation to persons' (Munyaka \& Motlhabi 2009:66). Identity is thus given by the community to the person or individual, and the individual is also constitutive of the community.

This reminds of Demasure and Müller's (2006:415) description of the way in which identity is seen through the lens of social-constructionism, where a 'relational self' is proposed. From the discourses available in a specific culture, for example, gender, education, age, sexuality and identity are coconstructed by the community and the individual (cf. Burr 1995:29; cf. Gergen 1999:6ff.).

For social-constructionism identity, thus flows out of relationships, relationships between different meanings are attributed to different experiences forming a part of larger discourses. People are described in terms of the discourses that are relevant at a specific time. If identity in $u b u n t u$ flows out of the relationships that humans have with other humans, the dead and nature, social-constructionism may be able to look more closely at the different kinds of relationship that are prevalent. Does the form of these relationships differ? If so, how and why? Do some have more might, just as certain discourses carry more weight in different times in socialconstructionist thought?

As social-constructionism views reality and knowledge as constructed by the relationships between different meanings and discourses, it will be well equipped to analyse the different ways in which $u b u n t u$ values are constructed, as relationships are constitutive of it. However, it also has the critical tools to unpack some of the meanings and connections perceived, by establishing whether or not language gives structure to meaning and leads to action in ways that are similar to some other cultures.

Relatedness thus pervades the African way of thinking, and is transmitted from generation to generation through different kinds of narratives (Murove 2009a:29).

Demasure and Müller (2006:414) also note this about the narrative hermeneutic metaphor: 'People act in the world and tell stories about it'. Narratives from embodied past lives form the basis for the ethics of embodied lives lived at the present time. Ricoeur also suggests that stories are the way in which people's transformation can be most easily achieved (Demasure \& Müller 2006:412). Social-constructionism also sees the importance of language and the structure it gives to us to relate our experiences into meaning (Demasure \& Müller 2006:414).

Mutwa (1998) writes about the stories that were passed from generation to generation by the historians and custodians of African culture:

It is through these stories that we are able to reconstruct the past of the Bantu of Africa. It is through these stories that intertribal friendship or hatred was kept alive and burning; [...] In short, it is these stories that shaped Africa as we know it - years and years ago [...]. (p. xvii)

Relatedness, identity, personhood, humanity and different kinds of narratives are thus both in accordance with the narrative approach of doing research, and essential parts of the ubuntu and the African way of life:

An ethical act worthy of approval is, thus, one that preserves and incorporates the past into the present with the aim of providing the same memory for future generations. Past, present and future are therefore internally related in such a way as to express an existential symbiosis. (Murove 2009a: 27)

Narratives are also used by different scholars to relay descriptions of actions where $u b u n t u$ is seen as the driving force, and narratives are used as evidence of the characteristics of ubuntu (cf. Prozesky 2009:10; Shutte 2009:85). Prozesky uses a specific narrative as a 'real life example' of ubuntu in practice.

I will now try to position myself through my own narratives and the meaning that I have formed from them in conjunction with the cultural contexts and dominant discourses alive at the time. These narratives will then be the basis on which I will try to understand some aspects of $u b u n t u$, the ways in which $u b u n t u$ as a concept has been used and misused, and the instances where $u b u n t u$ seems to have been lacking.

\section{Some narratives}

As stated earlier, I am white, Afrikaans and male. I am currently employed by the Dutch Reformed Church, and grew up on a farm. These descriptions all contain endless amounts of baggage, especially in South Africa. I am probably not aware of all the meanings, which are symbolised by this collection of words. Moreover, I am writing in my second language. However, I can try to relate all the meanings that I am consciously aware of in such a way to explain my position as someone doing research on $u b u n t u$ in South Africa.

My first memories are of life on the farm, of my parents and brother, the workers, their children, the daily activities of a farm. Getting up early and eating pap with some of the workers. 
I remember the relationships on our farm. There were hard words, I mostly gathered from the tone of voice, as I did not understand enough isiZulu. However, the majority of relationships and encounters were humane, normal.

Many of the workers' sons did vacation work on the farm during the school holidays. One of them, whose father was the main mechanical worker on the farm, started learning his father's trade during these holidays. He left school after completing grade 10, and started working on the farm full time. In the space of a few years, he had mastered his father's trade, learned carpentry, plumbing and electrical wiring, under the tutoring of both his and my father. After marrying and having his first child, he moved to Phuthaditjaba to start his own business. By the time he left, my father was already concerned about his health; he had lost a lot of weight, had sores across his whole body, and complained of a lack of energy.

He returned a few months later. His wife and child had died and he was very ill. I remember my father being irritated by the attitude that the nurses of the local mobile clinic had towards the medical problems of our workers. My father pleaded with the nurses for medical tests to be carried out on this worker, to try to figure out what was wrong and what could be done. They gave him medicine for a stomach ulcer; he died a few months later. The last week he worked, it took him fifteen minutes to walk the two hundred metres between his workshop and my father's office. At the time, the government was reluctant to address the issue of HIV and AIDS. We may be called racist for thinking that he had died of AIDS or a related disease. However, what if it was, and what could have happened if the government's policies were different?

With time, my parents experienced more and more labour issues, although there never was a culture of distrust or hatred. The incidents of problematic relations increased, however, in most cases caused by union officials. In one case, a worker resigned, and left without working during the 30 days' notice period. He returned a few weeks later, angry and cursing. The union official had explained to him that if he resigned he would receive Unemployment Insurance Fund benefits, but he was denied the benefits, therefore it must have been my father's doing that he did not receive these benefits. My father phoned the official to solve the matter, and the official claimed that it was in fact my father's doing, as my father had noted the reason for the end of employment on the relevant form, as resignation. According to the official, my father should have written 'fired', and then the worker could indeed receive the benefits. My father asked the official if he was supposed to lie, the official replied 'no', just change the reason for ending his employment. My father was fuming. The Commission for Conciliation, Mediation and Arbitration (CCMA) decided in my father's favour. In every instance he has been charged before the CCMA, the case was decided in his favour. Nobody in our family was glad about these decisions. Some of my friends' parents did not employ workers who were part of unions - they subsequently did not have these kinds of troubles.

In 1994, I entered grade 1, as well as the school hostel for boys. We were six grade one boys sharing a dormitory, all of us coming from farms. I remember how the six of us wisely talked politics, being thankful to 'Mandela' for all the school holidays during that year. I also remember how different the discussions in our house were from those in the houses of my friends.

Sometime during our third year at school, the first black pupil moved into the hostel. He was roomed with one of the senior boys. After that, other black pupils and an Indian pupil moved in with time. There was a commotion once when some of the senior white pupils tried to force the Indian pupil to read the Bible in the ten minutes allocated for Scripture and prayer in the mornings before breakfast.

For some reason the hostel for high school pupils was not managed as well as the one for primary school pupils. More and more parents of white children removed their children from the high school altogether, and enrolled them in neighbouring towns.

One of the significant problems was a total lack of discipline. I remember some of the boys in our hostel saying this was because most of the kids in that hostel were black pupils. The next day one of the white pupils staying in the hostel for high school pupils, whom we knew well from his stay in the primary school hostel, told us how the previous week he had sneaked through the ceiling of his room, through the roof to where his girlfriend stayed, and that he had stayed there with her for the night.

My parents were worried that the high school hostel would be closed down eventually; they did not want to have to send us to another town further away from home. They bought a house in town, and opened it as a private hostel. At the first parents' meeting, my parents supported the inclusion of black children; all the parents there voted against this idea. As time went by I remember wondering why my parents' opinions were so different from the opinions of my friends' parents, and the unease which I experienced taking part in conversations on some issues, especially race. I also remember not making any close black friends at school.

A female teacher was the head of the private hostel, and about 10-15 white children lived there. It was not long, maybe a month or two, before serious problems arose: discipline again. A set of rules was agreed upon by the parents at the opening of the house, but was mostly flatly ignored by their own children. I remember a good friend saying that his father would only let him stay there if the discipline was very strict; ironically, he was part of a group of children who did not have respect for any of the rules his father was so adamant about. One specific incident to this day stands out in my memory: a girl and a boy, both Afrikaners and both vocally 
racist, saw that one of the chairs in the dining room had a broken leg. They took the chair, and broke it until there were only a few pieces of discarded, useless wood left.

I remember being confused and uncomfortable at the way these boarders acted, especially because most of them were my closest friends. I especially remember not understanding how the same people who daily bemoaned the actions of black people could ignore the rules of the house they were staying in - never admitting to any fault on their side. Trying to enforce the rules was impossible. Another parent was adamant at the opening of the house that strict discipline should be applied. She also had the habit of climbing in her car and driving the fifty kilometres to town from their farm every time the teacher dared to discipline her child. It was a fiasco. My parents took a lot of strain, and eventually grew tired of all the problems they encountered managing this house.

Eventually the hostel for high school children was closed down, and we were accommodated in the hostel for primary school children. I remember that although the same children remained my friends, after the experiences at that house, things were never quite the same - for me at least.

In our grade 2 year, the first black child started playing rugby for our school. He was soon called 'Chester', and as the season passed, we learned that any other black child playing for any of the other schools was also called 'Chester'. We played trials for the local provincial cricket team in our grade 4 year, a black child who had only learned to hold a bat on the day of the trials was selected, and a friend of mine who was really good was left out. At about the time we were in grade 7 one of the black pupils in our year became one of the best rugby players in the school.

Somewhere in high school, I remember becoming aware of, and irritated that our school faced many more internal issues than the schools we competed against in sports leagues. Most of the schools in our league were exclusively white, with a few had black pupils. I do not remember a racial issue escalating to any noteworthy level, but I remember that the school was sometimes 'softly' divided at a racial level. There was always a lot of banter, especially in the sports teams, but this happened naturally and was usually done in a good spirit. In most teams, there were kids whose parents were either in the Conservative Party, and maybe even supporters of the Afrikaner Weerstandsbeweging, and black children of various political dispositions. I do not remember a black pupil complaining about racial discrimination in the sports teams, but that could easily be because of my own ignorance.

In 2004, my grade 11 year, we had a sports event at another school in our league. We drove in two buses; one had mostly white children, the other mostly black children, not by design as far as I could tell. We arrived, tired from the drive, and in a hostile environment. There was always a parent or pupil from the other schools' teams making insinuating remarks about race; usually it did not escalate into incidents where any noteworthy action was taken.

This day was different. From the moment of our arrival, there was a tangible tension in the air. I was watching one of the junior games from the main stadium, when the opposing team scored a try against our team. The conversion kick was unsuccessful, and one of the black players from our school caught the ball in the in goal area and touched down. A cry rang out from one of the opposing team's parents: 'Los ons bal jou kaffer!' ('Leave our ball you kaffer!')(sic).

Earlier in that season a rule had been instated across our rugby league: there was to be a three-metre no-go zone next to the touchlines of the field, where only touch judges, coaches and reserve players were allowed. In some cases, the no-go zone was made even wider. This was the result of multiple instances of violence between the parents of different schools playing sport against each other. As far as I remember, the incidents were all between white people, either parents on parents, or parents on players.

As we ran onto that field for the main game, we ran into a wall of parents of the opposing team, right on the touchline opposite the main stadium. In addition, even before the kickoff racial slurs started raining down on us. The parents from the opposing school made derogatory remarks against the black players on our team and towards the white players on our team, for daring to play in a team with black players. For the whole first half there were no incidents. However, early in the second half a black player on our team, playing inside centre, put in a hard tackle on his opposing player, the tackled player reacted and threw a punch. After sustaining a barrage of racial abuse for more than half an hour, our inside centre returned a punch and knocked the opposing player out cold. All hell broke loose.

One of the players on our team was nicknamed Witvoet (White foot) and his older brother was nick named Witwolf (White wolf), after the right-wing extremist Barend Strydom. As the fight broke out I saw him rushing towards the inside centre on our team. After reaching him, Witvoet started hitting out at all the players of the opposing team near to him. The two stood next to each other, throwing punches for the same side. For a few minutes, the Rainbow Nation miracle shone through utter darkness. When parents and children swamped the field, the game was stopped.

A week later, the incident was reported in Rapport. A one sided story was told by the player who had thrown the first punch as well as his mother, screaming racism and threatening with civil law suits (cf. Van Wyk 2004).

A year later, we were driving to another town for a rugby match. One of the white players, originally from a farm, starting mocking one of the black players in our team, telling him that one day he, the black player, would be a farm worker, working for the white player. It backfired, the white 
player's parents had lost their farm a few years earlier after running into financial trouble and the black player's uncle had just bought a rather large farm. The black player replied in kind, and the white boy sat down and looked gloomily out of the window without saying another word.

I moved into a residence for my first year at university. Riding on the wave of excitement of this new experience, I quickly became frustrated at the amount of black students who lived in the residence but did not partake in any of the events against other residences.

At the start of the first recess, I was on my way home when the two students living next to me came walking into the residence. I asked them when they would be leaving for home, and they replied that they were going to stay in the residence for the whole of the recess, as it was better staying there than going back to a shack in Soweto. My frustration subsided.

In our third year, another student and I were eating lunch in the dining room when he started talking about his experiences at university. He comes from a small town in Venda, and a school with only the most primitive resources. He told me how the black students who studied on bursaries started calling November 'Ramadan', because by then the money allotted them for food was depleted, and they survived on water and very little bread. He also laughed at himself: all first years had to attend a module on computer literacy, when he walked into the first class and was seated in front of a computer, the lecturer said: 'Open Windows'. The student stood up and searched the room for windows, but there were none.

These and other similar events are part of the narratives of meaning in my life and the life of others. They have shaped my thinking on every aspect of life: on race, culture, politics, economics, social issues, South African and Afrikaner identity and on faith. They are also the narratives that inform the questions I will ask. These are the networks of understanding from where I will be asking questions. As a white, Afrikaner, male person, I sometimes have doubts about whether my bona fides will be accepted. I know that what I have written with anger at some people; I need to know that it is worth something.

\section{Questions}

I will now try to use these narratives to frame certain questions that grow out of them and out of the events that unfold in South Africa over time. Mostly the questions come from perceived ambiguities, something that intrigues me personally, in Afrikaner culture, but also in other cultures: African cultures, as well as ways of being like ubuntu.

What does ubuntu mean for the distribution of resources, the distribution of state resources, is money spent on luxury cars whilst poverty, hunger and poor health permeate parts of the country part of an ubuntu ethic?
I can easily agree with the tenets of $u b u n t u$, but I struggle to see it as a lived reality, just as much as I struggle to see the Christian idea of neighbourly love as a lived reality. What constitutes the live reality of ubuntu in South Africa in 2015?

Coming from a farm, land restitution is a close and emotional issue. It has to happen, but what about white farmers who aquire even more land when struggling black farmers need help and sell their land. What about the farms that have been acquired for restitution, but that lie unused, untilled, and useless What would be the ubuntu values either present or not present in these situations?

I also understand that affirmative action and racial quotas are needed to transform South African society and remedy the evils of the past. This becomes more difficult when it affects people I know, especially when part of a generation that did not vote an apartheid government into power.

What are the reasons when in events or narratives the values of $u b u n t u$ are not percieved, in a cultural setting where it is accepted and promoted as values? Are these less beautiful narratives the result of an absence of $u b u n t u$, as Munyaka and Motlhabi suggest (2009:81)? Can Christians then claim the same when narratives of disturbing acts by Christians are related? Can Christians claim that apartheid was merely the absence of Christianity, and not the result of a perverted Christianity?

If it is possible to distuinguish between different 'varieties' of sexisms (Mazrui 2009:40), is it possible to distinguish between different varieties or levels of racism? What would benelovent, benign and malignant racism look like? Is there a difference between a farmer who pays his workers nothing but maize meal, and a farmer who patronises his workers but ensures that they always have food and that their children go to good schools? Does one of them look after the shared humanity of others?

What would it mean for me, as an Afrikaner, to be part of an Africa where 'I feel the other, I dance the other, ad therefore I am' (Senghor in Nussbaum 2009:101).

\section{Conclusion}

The aim of this article is to problematise the position of a specific researcher in a specific context. An Afrikaner man, doing research on $u b u n t u$, in a post-apartheid South Africa.

I started by laying out a theological and philosophical framework for doing practical theology in a research project on ubuntu. I then tried to show that the tools that will be used in this framework is compatible with a worldview such as ubuntu. Using autoethnography I then unpacked some of the narratives that have shaped my worldview, especially in relation to race and culture. I have also asked questions on the basis of my narratives, as well as a limited knowledge of ubuntu. These are the first steps in a research journey that will hopefully enrich the narratives that I have lived, 
as well as helping me understand the different narratives of ubuntu, to help me, as a white, Afrikaner 28-year old male, do meaningful and credible research on a subject for which these descriptions are part of a very painful history.

\section{Acknowledgements Competing interests}

The author declares that he has no financial or personal relationships which may have inappropriately influenced him in writing this article.

\section{References}

Aboobaker, S., 2014, 'Zokwana, pay your worker minimum wage', viewed 21 February 2015, from http://www.iol.co.za/news/politics/zokwana-pay-your-worker-minimumwage-1.1698461\#.VPPDgvmUd1Y

Burr, V., 1995, An introduction to social constructionism, 1st edn., Routledge, London. http://dx.doi.org/10.4324/9780203299968

Butz, D. \& Besio, K., 2004, 'The value of autoethnography for field research in transcultural settings', The Professional Geographer 56(3), 350-360.

Demasure, K. \& Müller, J.C., 2006, 'Perspectives in support of the narrative turn in pastoral care', Nederduits Gereformeerde Teologiese Tydskrif $47(3$ \& 4), 410-419.

Ellis, C. \& Bochner, A.P., 2000, 'Autoethnography, personal narrative, reflexivity: Researcher as subject', in N.K. Denzin \& Y.S. Lincoln (eds.), The handbook of qualitative research, 2 nd edn., pp. 733-768, Sage Publications, Newbury Park, CA.

Ember, C.R., Ember, M. \& Peregrine, N., 1998, 'Cross-cultural research', in H.R. Bernard \& C.C. Gravlee (eds.), Handbook of methods in cultural anthropology, 2nd edn., n.p., Rowman \& Littlefield, MD.

Freedman, J. \& Combs, G., 1996, Narrative therapy: The social construction of preferred realities, 1st edn., Norton, New York.

Gergen, J.K., 1999, An invitation to social constructionism, Sage Publications, London.

Hallen, B., 2009, A short history of African philosophy, 2nd edn., Indiana University Press, Bloomington, IN.

Leavy, P., 2009, Method meets art: Arts-based research practice, The Guilford Press, New York.

Mazrui, A.A., 2009, 'Africa's wisdom has two parents and one guardian', in M.F. Murove (ed.), African ethics: An anthology of comparative and applied ethics, n.p., University of KwaZulu-Natal Press, Scotsville, KY.
Mbiti, J.S., 1969, African religions and philosophy, Heinemann Educational Books Ltd, London.

Müller, J.C., 2005, 'A postfoundationalist, HIV-positive practical theology', Practical Theology South Africa 20(2), 72-88.

Müller, J.C., 2011, 'Postfoundational practical theology for a time of transition', HTS 67(1), 1-5. http://dx.doi.org/10.4102/hts.v67i1.837

Munyaka, M. \& Motlhabi, M., 2009, 'Ubuntu and its socio-moral significance', in M.F. Murove (ed.), African ethics: An anthology of comparative and applied ethics, n.p., University of KwaZulu-Natal Press, Scotsville, KY.

Murove, M.F. (ed.), 2009a, African ethics: An anthology of comparative and applied ethics, University of Kwazulu Natal Press, Scottsville, KY

Murove, M.F., 2009b, 'Beyond the savage evidence ethic: A vindication of African ethics', in M.F. Murove (ed.), African Ethics: An anthology of comparative and applied ethics, n.p., KwaZulu-Natal University Press, Scotsville.

Mutwa, V.C., 1998, Indaba, my children, Payback Press, Edinburgh.

Ndenze, B., 2015, 'Zuma may face hate speech charge', viewed 27 February 2015, from http://mobi.iol.co.za/\#!/article/zuma-may-face-hate-speech-charge-1.1804622

Nussbaum, B., 2009, 'Ubuntu: Reflections of a South African on our common humanity', in M.F. Murove (ed.), African ethics: An anthology of comparative and applied ethics, KwaZulu-Natal University Press, Scotsville.

Polkinghorne, D.E., 2007, 'Validity issues in narrative research', Qualitative Inquiry 13(4), 471-486. http://dx.doi.org/10.1177/1077800406297670

Praeg, L., 2014, A report on ubuntu, University of KwaZulu-Natal Press, Scotsville.

Prozesky, M.H., 2009, 'Cinderella, survivor and saviour: African ethics and the quest for a global ethic', in F.M. Murove (ed.), African ethics: An anthology of comparitive and applied ethics, University of KwaZulu-Natal Press, Scottsville.

Ricoeur, P., 1981, Hermeneutics and the human sciences, Cambridge University Press, London.

Routledge, 2000, Concice Routledge encyclopedia of philosophy, Routledge, London.

Sarup, M., 1988, An introductory guide to post-structuralism and postmodernism, Harvester Wheatsheaf, Hertfordshire.

Schingaro, N., 2014, 'The reversal of lifelong labeling: An autoethnography', Deviant Behavior 35(9), 703-726. http://dx.doi.org/10.1080/01639625.2013.878578

Shutte, A., 2009, 'Ubuntu as the African ethical vision', in M.F. Murove (ed.), African ethics: An anthology of comparative and applied ethics, n.p., University of KwaZulu-Natal Press, Scotsville.

Taber, N., 2010, 'Institutional ethnography, autoethnography, and narrative: An argument for incorporation multiple methodologies', Qualitative Research 10(1), 5-25. http://dx.doi.org/10.1177/1468794109348680

Van Huyssteen, J.W., 2006, Alone in the world? Human uniqueness in science and theology, William B. Eerdmans Publishing Company, Grand Rapids, MI.

Van Wyk, M., 2004, 'Seun dien klag in en ma wil eis ná "geniepsige rugby"', viewed 23 February 2015, from http://152.111.1.87/argief/berigte/rapport/2004/05/30/ R1/24/02.html 